Article

\title{
Flaccidoxide-13-Acetate-Induced Apoptosis in Human Bladder Cancer Cells is through Activation of p38/JNK, Mitochondrial Dysfunction, and Endoplasmic Reticulum Stress Regulated Pathway
}

\author{
Yu-Jen $\mathrm{Wu}^{1,2,4, \dagger}$, Tzu-Rong Su ${ }^{3, \dagger}$, Guo-Fong Dai ${ }^{2,4}$, Jui-Hsin Su ${ }^{5}$ and Chih-I Liu ${ }^{1, *}$ \\ Department of Nursing, Meiho University, Pingtung 91202, Taiwan; x00002180@meiho.edu.tw \\ Department of Biological Technology, Meiho University, Pingtung 91202, Taiwan; fwind101@gmail.com \\ 3 Antai Medical Care Cooperation Antai Tian-Sheng Memorial Hospital, Pingtung 92842, Taiwan; \\ a081002@mail.tsmh.org.tw \\ 4 Yu Jun Biotechnology Co., Ltd., Kaohsiung 81363, Taiwan \\ 5 National Museum of Marine Biology and Aquarium, Pingtung 94450, Taiwan; x2219@nmmba.gov.tw \\ * Correspondence: x00002177@meiho.edu.tw; Tel.: +886-8-7799821 (ext. 8110); Fax: +886-8-7799711 \\ + These authors contributed equally to this work.
}

Received: 6 April 2019; Accepted: 5 May 2019; Published: 13 May 2019

check for updates

\begin{abstract}
Flaccidoxide-13-acetate, an active compound isolated from cultured-type soft coral Sinularia gibberosa, has been shown to have inhibitory effects against invasion and cell migration of RT4 and T24 human bladder cancer cells. In our study, we used an 3-(4,5-dimethyl-2-thiazolyl) -2,5-diphenyl-2-H-tetrazolium bromide (MTT), colony formation assay, and flow cytometry to determine the mechanisms of the anti-tumor effect of flaccidoxide-13-acetate. The MTT and colony formation assays showed that the cytotoxic effect of flaccidoxide-13-acetate on T24 and RT4 cells was dose-dependent, and the number of colonies formed in the culture was reduced with increasing flaccidoxide-13-acetate concentration. Flow cytometry analysis revealed that flaccidoxide-13-acetate induced late apoptotic events in both cell lines. Additionally, we found that flaccidoxide-13-acetate treatment upregulated the expressions of cleaved caspase 3, cleaved caspase 9, Bax, and Bad, and down-regulated the expressions of Bcl-2, p-Bad, Bcl-x1, and Mcl-1. The results indicated that apoptotic events were mediated by mitochondrial dysfunction via the caspase-dependent pathway. Flaccidoxide-13-acetate also provoked endoplasmic reticulum (ER) stress and led to activation of the PERK-eIF2 $\alpha$-ATF6-CHOP pathway. Moreover, we examined the PI3K/AKT signal pathway, and found that the expressions of phosphorylated PI3K ( $p$-PI3K) and AKT ( $p$-AKT) were decreased with flaccidoxide-13-acetate concentrations. On the other hand, our results showed that the phosphorylated JNK and p38 were obviously activated. The results support the idea that flaccidoxide-13-acetate-induced apoptosis is mediated by mitochondrial dysfunction, ER stress, and activation of both the p38 and JNK pathways, and also relies on inhibition of PI3K/AKT signaling. These findings imply that flaccidoxide-13-acetate has potential in the development of chemotherapeutic agents for human bladder cancer.
\end{abstract}

Keywords: flaccidoxide-13-acetate; cultured soft coral Sinularia gibberosa; human bladder cancer; apoptosis; mitochondrial dysfunction; PERK-eIF2 $\alpha$-ATF6-CHOP pathway; p38/JNK 


\section{Introduction}

In the US, bladder cancer is the second most frequent genitourinary malignant tumor, and is a fatal disease [1]. Most human bladder cancers belong to the category of transitional cell carcinoma, which can be further divided into invasive and non-invasive bladder cancer. T2 and higher stages of muscle invasive bladder cancer have a poor prognosis and a high risk of metastasis [2-4]. Non-muscle-invasive bladder cancer is usually treated with transurethral resection of the bladder tumor, followed by close monitoring or Bacillus Calmette-Guérin (BCG) instillation [5]. However, the recurrence rate in patients with high-grade non-muscle-invasive bladder cancer after transurethral resection exceeds $75 \%$, with a low survival rate [6]. Since the recurrence rate of bladder cancer is still high, and many medications currently used for bladder cancer have strong side effects [3], the development of new drugs for bladder cancer treatment remains an important issue.

Marine soft corals are rich in biologically-active substances, and have been shown to exert anti-inflammatory, anti-fungal, anti-viral, anti-cancer, and cytotoxic activities [7-10]. Cembrane -type diterpene are common secondary metabolites of marine and terrestrial organisms, and cytotoxicity is one of the major characteristics of compounds of this type [11-13]. Previous studies have shown that compounds extracted from soft corals, such as diterpenes, diterpenoids, and prostanoids can induce apoptosis in cancer cells, including colon cancer, oral squamous carcinoma, breast cancer, cervical cancer, hepatocellular carcinoma, bladder cancer, and melanoma cells [14-20]. The apoptotic process includes intrinsic and extrinsic pathways [21,22]. Studies have shown that many organelles in the cell may trigger the intrinsic pathway to induce apoptosis when stress occurs. Mitochondria and the endoplasmic reticulum (ER) are the two major organelles in which stress-induced apoptosis takes place [22-24]. Mitochondria provide the chemical energy required for cellular activities, and are the main components in the cell in which oxidative phosphorylation and adenosine triphosphate (ATP) synthesis take place [25].

Mitochondria are also involved in cell differentiation, cell signaling, and apoptosis, and have the ability to regulate cell growth and control the cell cycle [26]. During apoptosis, Bax translocates from the cytoplasm to the outer membrane of the mitochondria, and Bax and Bak oligomers form pores in the outer membrane, triggering mitochondrial dysfunction [27-29].

The functions of the ER include regulation of protein synthesis, protein folding, post-translational modification, and maintenance of intracellular calcium homeostasis [30]. When ER stress occurs, in order to relieve the stress and promote survival, cells need to initiate specific signaling pathways to limit protein synthesis, increase protein folding ability, and degrade misfolded proteins. The unfolded protein response (UPR) is a series of processes by which the ER transmits the stress signal from its lumen into the cytosol and nucleus. UPR-related genes are induced by UPR sensors, activating transcription factor 6 (ATF6) and inositol requiring enzyme $1 \alpha$ (IRE1- $\alpha$ ) in response to ER stress to promote correct protein folding. Another UPR sensory protein, PKR-like ER-associated kinase (PERK), detects an overload of biosynthetic protein folding in the ER, and initiates limitation of new protein synthesis by phosphorylation of eukaryotic initiation factor $2 \alpha(\mathrm{eIF} 2 \alpha)$ [23,31]. Additionally, cells may prevent excessive accumulation of misfolded proteins in the ER through ER-associated degradation (ERAD). If the level of misfolded proteins does not reduce, cells will undergo apoptosis via pathways involving IRE1- $\alpha$, caspase-12, and PERK/CHOP [32]. Moreover, results by scholars have shown that apoptosis in human bladder cancer cells is associated with endoplasmic reticulum stress [33-35].

Flacidoxide-13-acetate is a cembrane-type diterpene extracted from the cultured soft coral Sinularia gibberosa. Our previous study revealed that flacidoxide-13-acetate reduces cancer cell migration and invasion in T24 and RT4 human bladder cancer cell lines [36]. In this study, we investigated the mechanisms of its apoptotic and antiproliferative activities in human bladder cancer, and aimed to provide useful information to inform the development of flacidoxide-13-acetate as a new drug for bladder cancer treatment. 


\section{Results}

\subsection{Flaccidoxide-13-Acetate Inhibited Human Bladder Cancer Cell Proliferation}

An 3-(4,5-dimethyl-2-thiazolyl)-2,5-diphenyl-2-H-tetrazolium bromide (MTT) and a colony formation assay were used to study the cytotoxic effects of flaccidoxide-13-acetate on T24 and RT4 bladder cancer cell lines. The MTT assay showed that the survival rates of T24 and RT4 cells were dose-dependently decreased. As shown in Figure 1A, flaccidoxide-13-acetate at a concentration of $20 \mu \mathrm{M}$ inhibited cell survival by $40 \%$. The colony formation assay demonstrated that the numbers of colonies also reduced with increasing flaccidoxide-13-acetate concentrations $(5,10,15$, and $20 \mu \mathrm{M})$ in both RT4 and T24 cells (Figure 1B). The results indicate that flaccidoxide-13-acetate has the ability to suppress cell proliferation in these two bladder cancer cell lines.

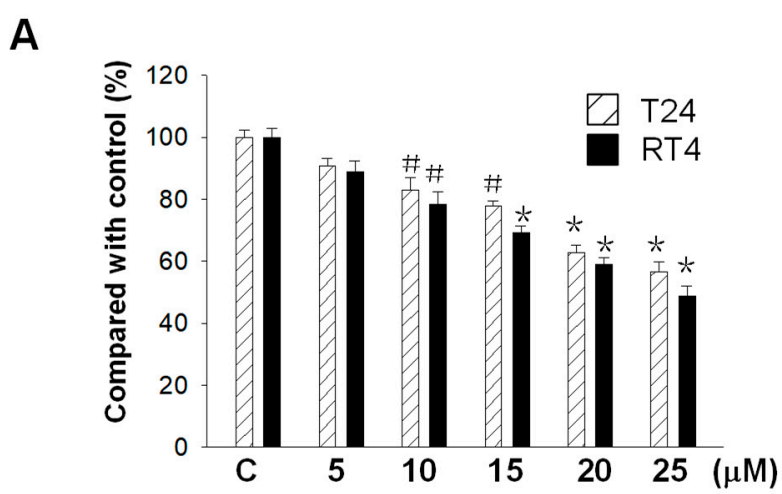

B
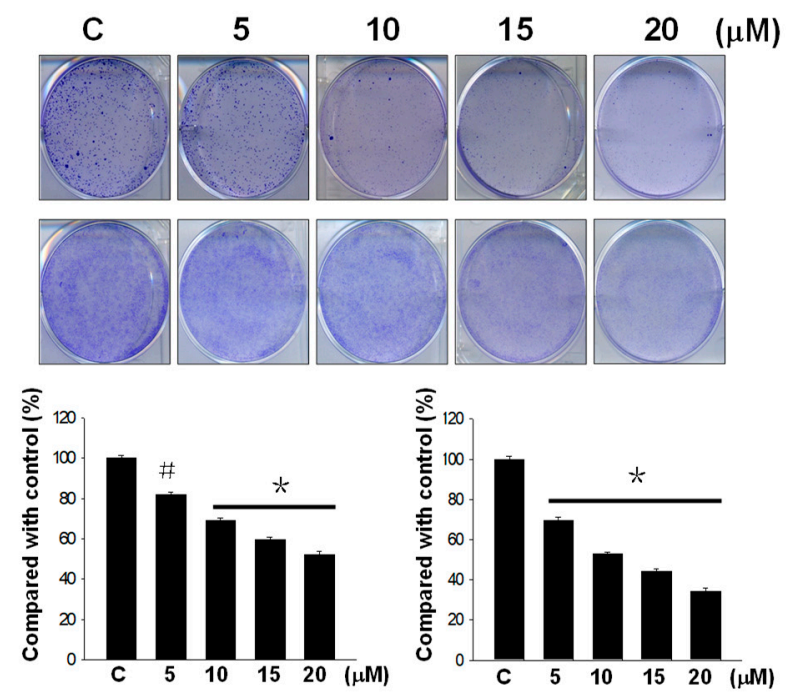

Figure 1. (A) Cytotoxic effects of flaccidoxide-13-acetate $(0,5,10,15,20,25 \mu \mathrm{M})$ on T24 and RT4 cell lines. T24 and RT4 cells were incubated with the indicated flaccidoxide-13-acetate concentrations for $24 \mathrm{~h}$, and the cell numbers were assessed using an 3-(4,5-dimethyl-2-thiazolyl)-2,5-diphenyl-2-H-tetrazolium bromide (MTT) assay. The results were obtained from three individual experiments. (B) Effects of flaccidoxide-13-acetate on colony formation in RT4 and T24 cell lines. The cells were treated with various $(5,10,15$, and $20 \mu \mathrm{M})$ concentrations of flaccidoxide-13-acetate and cultured for 10 days. The numbers of colonies were counted and the results were normalized to a culture without flaccidoxide-13-acetate treatment $(100 \%)$. Data are presented as mean \pm S.D. of triple replicate experiments. $\left({ }^{\#} p<0.05 ;{ }^{*} p<0.01\right.$, compared with the control.) 


\subsection{Flaccidoxide-13-Acetate Induced Apoptosis in RT4 and T24 Cells}

The results presented in Figure 1 show that flaccidoxide-13-acetate had cytotoxic effects and inhibited cell proliferation in RT4 and T24 cell lines. We next used fluorescein isothiocyanate (FITC)-labeled annexin with propidium iodide (PI) to perform flow cytometry analysis to examine the apoptotic events in flaccidoxide-13-acetate-treated RT4 and T24 cells. As shown in Figure 2, compared with the control (3.4\%), the percentages of late apoptotic cells in cell cultures treated with 5, 10 , and $15 \mu \mathrm{M}$ flaccidoxide- 13 -acetate were $11.0 \%, 11.9 \%$, and $17.6 \%$ in T24 cells, and $17 \%, 20.2 \%$, and $29.1 \%$ in RT4 cells, respectively. The dose-response results demonstrate that flaccidoxide-13-acetate induced late apoptotic events in both cell lines.

\section{T24 cells}
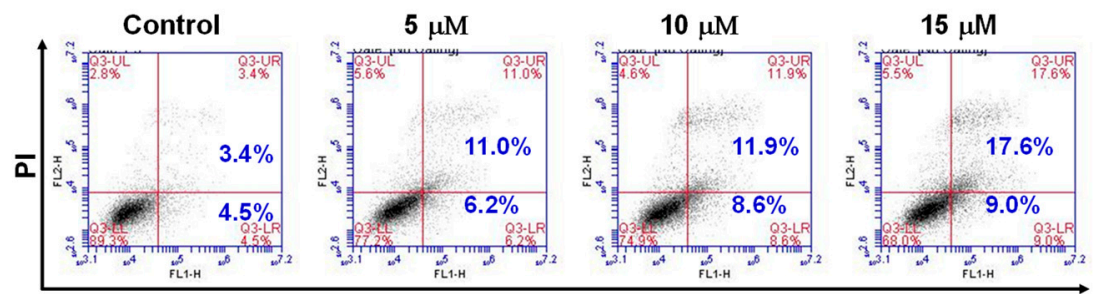

Annexin V-FITC

RT4 cells
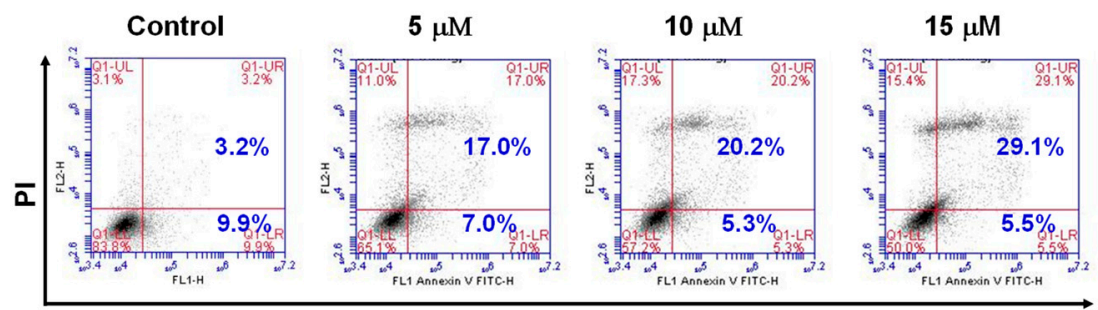

Annexin V-FITC

Figure 2. Detection of apoptosis in flaccidoxide-13-acetate-treated RT4 and T24 cells by flow cytometry analysis.

\subsection{Flaccidoxide-13-Acetate Initiated Mitochondrial Dysfunction in T24 and RT4 Cells}

Mitochondrial dysfunction is known to be associated with apoptosis [27-29]. As flaccidoxide-13-acetate was found to induce a late apoptotic response in RT4 and T24 cells (Figure 2), we next examined whether flaccidoxide-13-acetate-induced apoptosis is mediated by mitochondrial dysfunction. Using Western blotting, the expressions of Bax and Bad in the cells were analyzed, and the results showed that the expression levels of Bad and Bax increased with the increase in concentrations of flaccidoxide-13-acetate, while the expression levels of p-Bad Bcl-x1, Bcl-2, and Mcl-1 decreased (Figure 3). Mitochondria are membrane-bound organelles that play an essential role in maintaining biological homeostasis, and their normal functions are controlled by Bcl-2 family proteins [37]. When cells are under stress or injured, the intracellular calcium homeostasis is disturbed, resulting in the opening of mitochondrial permeability transition pores. This results in the pro-apoptotic protein Bax being overexpressed and residing in the outer mitochondrial membrane, further forming a heterodimer with Bcl-2. It also leads to changes in the mitochondrial transmembrane potential and cytochrome $C$ (Cyt $C$ ) release into the cytosol. Moreover, we also performed Western blotting to examine the effect of flaccidoxide-13-acetate on the activation of caspase 9, caspase 3 , and PARP-1 cleavage. The results demonstrated that flaccidoxide-13-acetate treatment up-regulated expression levels of cleavage-PARP-1, cleavage-caspase 3 , and cleavage-caspase 9 , and down-regulated expression levels of pro-caspase 3 and pro-caspase 9. Our results showed that flaccidoxide-13-acetate 
induced mitochondrial dysfunction and the compounds increased active caspase level, leading to apoptosis in T24 and RT4 cells.

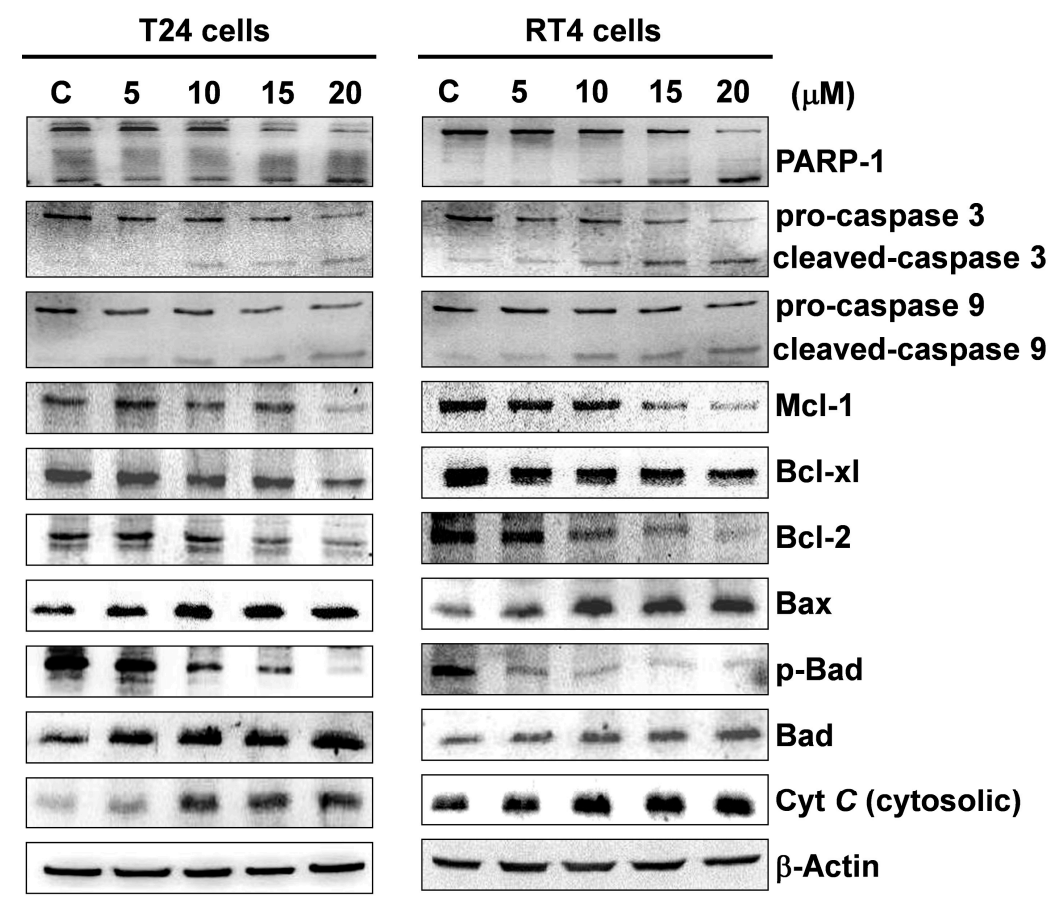

Figure 3. Western blotting analysis of the expressions of Bcl-2 family proteins and cytochrome $C$ after flaccidoxide-13-acetate-treated in RT4 and T24 cells. With increased flaccidoxide-13-acetate concentrations, the expressions of Bax, Bad, and Cyt $C$ were increased, but Mcl-1, Bcl-xl, Bcl-2, and $p$-Bad were decreased.

\subsection{Flaccidoxide-13-Acetate Activated the $p 38$ and JNK Pathways and Inhibited the PI3K/AKT Pathway}

The mitogen-activated protein kinase (MAPK) signaling pathway plays important roles in regulating several key cell functions, including gene expression, cell proliferation, and apoptosis [38]. We used Western blotting to analyze the changes in key proteins in the MAPK signaling pathway. The results showed no significant changes in non-phosphorylated ERK, JNK, and p38, while the levels of phosphorylated p38 ( $p$-p38) and JNK ( $p$-JNK) were increased with the increase in flaccidoxide-13-acetate concentrations.

We next examined the PI3K/AKT signal pathway, and found that the expressions of phosphorylated PI3K ( $p$-PI3K) and AKT ( $p$-AKT) were decreased with the increase in flaccidoxide-13-acetate concentrations (Figure 4). We also used the p38 inhibitor (SB203580), JNK inhibitor (SP600125), and ERK inhibitor (PD98059) to validate whether apoptosis induced by flaccidoxide-13-acetate is mediated by activation of the MAPK pathway. The results demonstrated that cells pre-treated with SB203580 and SP600125, followed by incubation with flaccidoxide-13-acetate, exhibited an increase in the cell survival rate from $60 \%$ to approximately $80 \%$, while PD98059 did not improve cell survival (Figure 4B). The abovementioned findings suggest that flaccidoxide-13-acetate-induced apoptosis in RT4 and T24 cells involves activation of the JNK and p38 pathways and inhibition of the PI3K/AKT pathway. 
A

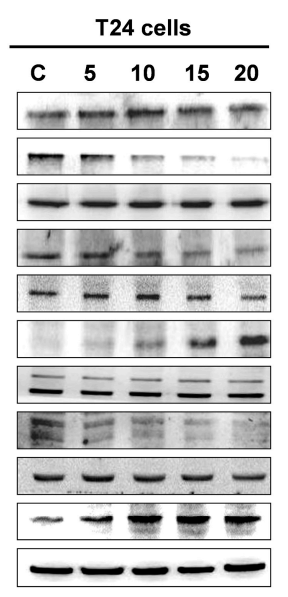

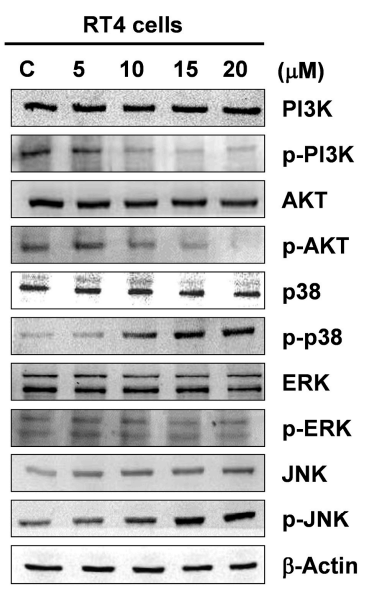

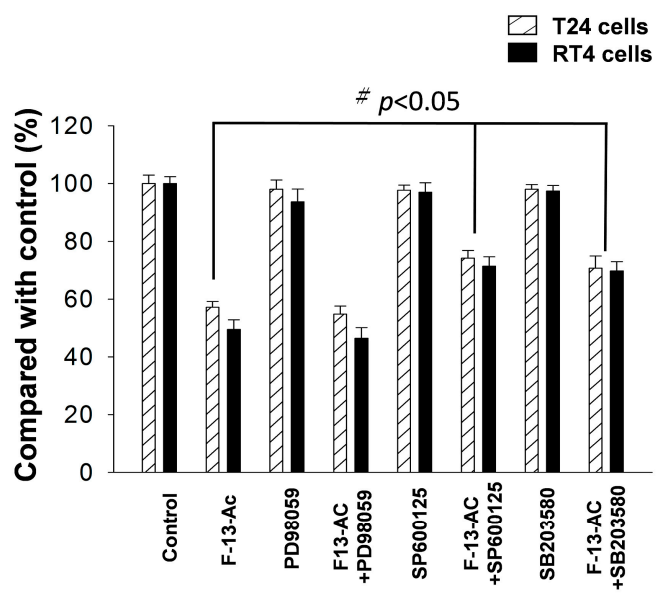

Figure 4. (A) Western blotting analysis of the expressions of PI3K/AKT and mitogen-activated protein kinase (MAPK) pathway-related proteins in RT4 and T24 cells after administration of flaccidoxide-13-acetate treatment. (B) Flaccidoxide-13-acetate-induced apoptosis in T24 and RT4 cells is mediated by activation of p38 and JNK pathway using ERK-, JNK-, and p38-specific inhibitors. (F-13-AC: flaccidoxide-13-acetate). Data are presented as mean \pm S.D. of triple replicate experiments. $\left({ }^{\#} p<0.05{ }^{*} p<0.01\right.$, compared with the control).

\subsection{Endoplasmic Reticulum Stress is Involved in Flaccidoxide-13-Acetate-Induced Apoptosis}

ER is sensitive to changes in internal and external factors, such as calcium ion concentration change and protein misfolding caused by viral infection. ER stress affects the maintenance of normal cellular functions and may even affect cell survival [39]. The ER stress response constitutes a cellular process, and may lead to unfolded protein response (UPR), ER-associated degradation (ERAD), and apoptosis [40,41]. The UPR is regulated by three ER sensors: inositol requiring enzyme 1- $\alpha$ (IRE1- $\alpha$ ), protein kinase RNA-like endoplasmic reticulum kinase (PERK), and activating transcription factor 6 (ATF6). When misfolded proteins accumulate in the ER, ER chaperones (such as GRP78) release transmembrane sensor proteins PERK, IRE1- $\alpha$, and ATF6, activating the UPR. In addition, PERK may regulate the signaling pathway that causes autophagy to promote cell survival [42] or increases ATF4/CHOP expression to induce apoptosis [43].

In this study, the changes in two ER transmembrane sensor proteins, PERK, ATF6, and other relevant proteins were analyzed using Western blotting. The results showed that the expressions of ATF6-f and GRP78 proteins increased in both cell lines treated with flaccidoxide-13-acetate; in addition, the levels of $p$-eIF2 $\alpha$ and $p$-PERK, as well as ATF4 and CHOP increased with the increase in concentrations of flaccidoxide-13-acetate (Figure 5). To confirm that ER stress is involved in apoptosis, we added salubrinal, an inhibitor of eIF $2 \alpha$ phosphorylation, into the culture, and found that cells treated with salubrinal exhibited a significantly increased survival rate (Figure 5B). The results further support that ER stress is associated with flaccidoxide-13-acetate-induced apoptosis. 
A

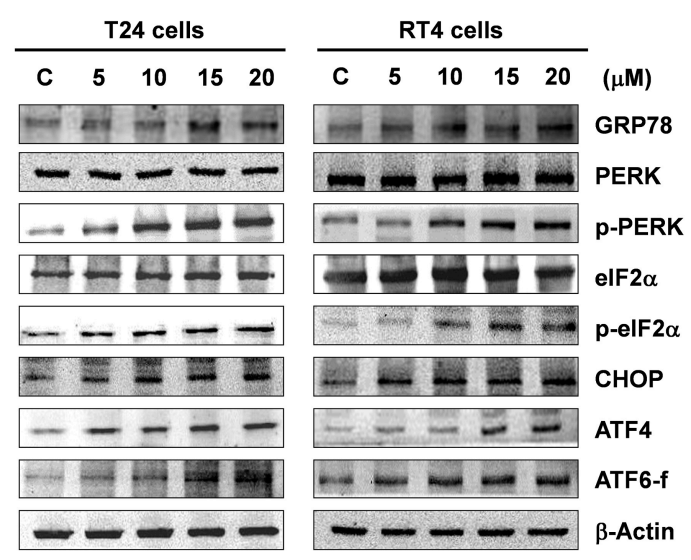

B

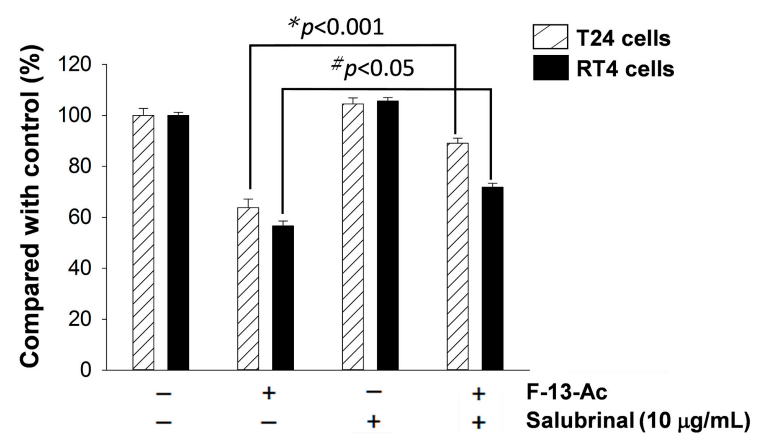

Figure 5. (A) Western blotting analysis of ER stress-related proteins in T24 and RT4 cells treated with flaccidoxide-13-acetate. (B) Effect of eIF2 $\alpha$ phosphorylation inhibitor salubrinal on the cell survival of the two cell lines treated with flaccidoxide-13-acetate.

\section{Discussion}

\subsection{Flaccidoxide-13-Acetate Triggers Mitochondrial Dysfunction in T24 and RT4 Bladder Cancer Cells}

The Bcl-2 family of proteins are regulators of apoptosis, and include distinct subfamilies: (1) proapoptotic proteins with a multi-BH domain (such as Bax and Bak); (2) proapoptotic proteins with a single BH3-only protein (such as Bad, Bim, and Bid), and (3) antiapoptotic members such as Bcl-2 and Bcl-xl with all four BH domains conserved (such as Bcl-2, Bcl-xl, and Mcl-1) [44]. Studies have shown that intracellular stress may trigger the intrinsic apoptotic pathway in several organelles; mitochondria and the ER are two of the major organelles involved [22-24]. In the presence of mitochondrial stress, Bax translocate to the outer membrane of the mitochondria and increases the membrane permeability, which causes alteration of the mitochondrial membrane potential, depolarization, and opening of mitochondrial pores [28].

We used Western blotting to analyze the changes in mitochondria-associated apoptotic proteins in flaccidoxide-13-acetate-treated T24 and RT4 cells, and found that Bax and Bad expressions were increased with increasing flaccidoxide-13-acetate concentrations, while the expressions of $p$-Bad Bcl-x1, $\mathrm{Bcl}-2$, and Mcl-1 were decreased. An increased ratio of Bax/Bcl-2 provokes the release of cytochrome $C$ from the mitochondrial intermembrane/intercristae spaces to the cytosol, where cytochrome binds to A-Raf-1, resulting in caspase 9 and downstream effector caspase-3 activation [45-48]. Activated caspase3 then cleaves PARP-1 to induce characteristic apoptosis changes, such as chromatin condensation and DNA fragmentation [49]. Our results imply that flaccidoxide-13-acetate treatment caused mitochondrial stress, which led to an increase in Bad expression and decreases in Bcl-2, Bcl-xl, Mcl-1, and $p$-Bad expressions, causing mitochondrial dysfunction. Additionally, the increase in Bax expression and the decrease in Bcl-2 expression resulted in an increased Bax/Bcl-2 ratio, which stimulated the release of cytochrome $C$ from the mitochondrial inner membrane into the cytosol. Our results also show that flaccidoxide-13-acetate treatment up-regulated expression levels of cleavage-PARP-1, cleavage-caspase 3, and cleavage-caspase 9, and down-regulated expression levels of pro-caspase 3 and pro-caspase 9. We hypothesize that the release of cytochrome $C$ causes procaspase 9 to self-hydrolyze into activated caspase 9, which in turn activates caspase 3 and cleaves PARP into its cleaved form. The process subsequently triggered apoptotic events, such as DNA fragmentation and chromosome condensation [49]. These results imply that flaccidoxide-13-acetate-induced apoptosis in both T24 and RT4 human bladder cancer cells are related to the pathway associated with activated mitochondrial apoptosis. 
3.2. Flaccidoxide-13-Acetate Induces Apoptosis through Activation of the p38 and JNK Signaling Pathways and Inhibition of the PI3K/AKT Pathway

The MAPK pathway regulates many stress-induced physiological processes, including cell differentiation, cell growth, and apoptosis $[50,51]$. Three well-characterized subfamilies of the MAPK pathway are mediated by JNKs, p38 kinases, and ERKs, respectively. Among these MAPKs, activation of JNKs and p38 kinases occurs in response to various intrinsic and extrinsic stimuli [51,52]. Study has shown that intracellular stress may induce $\mathrm{p} 38$ pathway activation and promote apoptosis by activation of p53 and inhibition of Bcl-2 expression [53]. ERK is important for cell proliferation and survival, and can be activated by mitotic stimuli, such as growth factors and cytokines [54]. Phosphorylated ERK has been shown to promote cell proliferation and inhibit pro-apoptotic signaling [55], and constitutive activation and overexpression of ERK are often observed in many cancer cells [56]. In this study, Western blotting showed that the total expressions of ERK, JNK, and AKT were found to be unchanged in T24 and RT4 cells treated with various concentrations of flaccidoxide-13-acetate, while the expressions of phosphorylated p38 and JNK increased significantly (Figure 4). When specific inhibitors of p38, JNK, and ERK were used, the results demonstrated that both the p38 inhibitor (SB203580) and the JNK inhibitor SP600125, but not the ERK inhibitor (PD98059), increased the cell viability, suggesting that flaccidoxide-13-acetate-induced apoptosis in RT4 and T24 cells is at least partly mediated by the p38 and JNK pathways.

The PI3K/AKT signaling pathway has been found to be activated in several types of cancer, and is known to regulate cell survival, proliferation, differentiation, and apoptosis [57]. Several downstream targets of AKT, such as GSK-3b, Bad, and NF- $\mathrm{kB}$, are known to directly or indirectly regulate apoptosis in many cancers $[58,59]$. Phosphorylation of Bad alters its binding ability to Bcl-2 and Bcl-xl by increasing its association with 14-3-3, resulting in loss of the ability of Bad to heterodimerize with survival proteins Bcl-2 and Bcl-xl $[60,61]$. Therefore, downregulation of the PI3K/AKT signaling pathway has been found to induce apoptosis in several studies $[62,63]$. We showed that RT4 and T24 cells under flaccidoxide-13-acetate treatment exhibited decreases in the expressions of phosphorylated PI3K and AKT expression, which indicates that flaccidoxide-13-acetate-induced apoptosis occurs through inactivation of the PI3K/AKT signaling pathway.

\subsection{Flaccidoxide-13-Acetate-Induced Apoptosis Occurs Partially via Initiation of ER Stress in T24 and RT4 Cells}

When cells are under ER stress, GRP78, which is involved in protein folding, initiates the release of transmembrane proteins PERK and IRE1- $\alpha$, and activates transcription factor ATF6. PERK signaling has been demonstrated to utilize autophagy as a survival strategy [42], or cause apoptosis through upregulation of ATF4 and proapoptotic transcription factor CCAA/enhancer binding protein (C/EBP) homologous protein (CHOP) [43]. Upon ER stress, transcription and protein synthesis are reduced due to eIF $2 \alpha$ being phosphorylated by $p$-PERK, and the ATF6 and IRE1- $\alpha$ signaling pathways induce the expression of ER chaperones [64-66]. When ER stress is prolonged, PERK is activated and phosphorylates eIF2 $\alpha$ [67,68]; phosphorylated eIF2 $\alpha$ subsequently activates ATF4, which targets the expression of apoptotic effector, CHOP [69]. Apoptosis is related to the expression of CHOP; expression of ATF4 is also positively correlated with CHOP. Thus, when ATF4 induces downstream $\mathrm{CHOP}$ protein expression, the cells will progressively switch from autophagy to apoptosis [70].

Our results demonstrate that the expressions of GRP78 proteins and ATF6 increased in both cell lines treated with flaccidoxide-13-acetate. In addition, the levels of $p$-PERK, $p$-eIF2 $\alpha$, and ATF4 as well as $\mathrm{CHOP}$ were increased with increase in concentration of flaccidoxide-13-acetate treatment (Figure 5A). To confirm that ER stress is involved in apoptosis, we added salubrinal, an inhibitor of eIF2 $\alpha$ phosphorylation, into the culture, and found that cells treated with salubrinal exhibited a significantly increased survival rate (Figure $5 B$ ).

These results imply that the apoptosis induced by flaccidoxide-13-acetate is partially mediated by the PERK-eIF2 $\alpha$-ATF4-CHOP pathway. These results are similar to the outcomes of Toeh et al.'s 
study [71]. When the function of the endoplasmic reticulum is disturbed, it will lead to ER stress that activates the expression of PERK and ATF6, then induces CHOP up-regulation of the PERK/ATF4/CHOP pathway and causes cell apoptosis

\section{Material and Methods}

\subsection{Reagents}

Flaccidoxide-13-acetate was isolated from cultured-type soft coral Sinularia gibberosa by Dr. Jui-Hsin Su. Dulbecco's modified Eagle's medium (DMEM), fetal bovine serum (FBS), and phosphate-buffered saline (PBS), were purchased from Biowest (Nuaillé, France). Polyvinylidene difluoride (PVDF) membranes were purchased from Millipore (Bellerica, MA, USA). Protease inhibitor cocktail, dimethyl sulfoxide (DMSO), salubrinal, and goat anti-rabbit and horseradish peroxidase-conjugated immunoglobulin (Ig) G were obtained from Sigma (St. Louis, MO, USA). Cell extraction buffer was acquired from BioSource International (Camarillo, CA, USA). An annexin V-FITC/PI apoptosis detection kit was purchased from Pharmingen (San Diego, CA, USA). The enhanced chemiluminescence (ECL) Western blotting reagents were obtained from Pierce Biotechnology (Rockford, IL, USA). Cytochrome $C$ releasing apoptosis assay kit was purchased form Biovision (Milpitas, CA, USA).

\subsection{Cell Culture and Drug Treatment}

Human bladder cancer RT4 and T24 cell lines were obtained from the Taiwan Food Industry Research and Development Institute (Hsinchu, Taiwan). The cell lines were cultured in Dulbecco's modified Eagle's medium (DMEM) supplemented with 10\% fetal bovine serum (FBS), $100 \mu \mathrm{g} / \mathrm{mL}$ streptomycin, and 100 units $/ \mathrm{mL}$ penicillin in a humidified $5 \% \mathrm{CO}_{2}$ incubator at $37^{\circ} \mathrm{C}$. Cells were treated with various concentrations of flaccidoxide-13-acetate and harvested after $24 \mathrm{~h}$ of incubation. DMSO was added to the control group, and cultured for $24 \mathrm{~h}$ for subsequent studies. All experiments were performed three times to determine their reproducibility.

\subsection{Cell Viability Assay}

The effects of flaccidoxide-13-acetate on the T24 and RT4 cell lines were evaluated by MTT assay. Cells $\left(1 \times 10^{5}\right.$ cells/well $)$ were seeded in 96 well plates. The cells were treated with various concentrations of flaccidoxide-13-acetate $(5,10,15,20$, and $25 \mu \mathrm{M})$. After $24 \mathrm{~h}$ of incubation, MTT solution $(0.5 \mathrm{mg} / \mathrm{mL}$ in PBS) was added to each well. The plates were incubated for $4 \mathrm{~h}$ at $37^{\circ} \mathrm{C}$, after which the culture medium was removed and the cells were dissolved in $200 \mu \mathrm{L}$ DMSO. The absorbance was measured at $595 \mathrm{~nm}$ using a microplate ELISA reader (Bio-Rad, Hercules, CA, USA) and DMSO was used as the control. Samples were analyzed and all experiments were repeated three times.

\subsection{Flow Cytometric Assay}

T24 and RT4 cells were seeded onto $5 \mathrm{~cm}$ petri dishes, treated with different concentrations of flaccidoxide-13-acetate for $24 \mathrm{~h}$. The cells were then collected and fixed in $70 \%$ cold ethanol at $4{ }^{\circ} \mathrm{C}$ overnight. The cells were subsequently stained with $10 \mu \mathrm{g} / \mathrm{mL}$ Annexin V-FITC and $5 \mu \mathrm{g} / \mathrm{mL}$ propidium iodide (PI) for 30 minutes at $37^{\circ} \mathrm{C}$. Apoptosis processes induced by flaccidoxide-13-acetate were analyzed using a FACScalibur flow cytometer and Cell-Quest software (Becton-Dickinson, Mansfield, MA, USA).

\subsection{Colony For mation Assay}

T24 and RT4 cells were seeded in 24 well plates (2000 cells/well) and incubated for $24 \mathrm{~h}$. The cells were treated with various concentrations $(5,10,15$, and $20 \mu \mathrm{M})$ of flaccidoxide-13-acetate in $2 \mathrm{~mL}$ of serum complete media and incubated for 10 days. The colonies were then washed with PBS and fixed with methanol for $15 \mathrm{~min}$ and stained with $0.15 \%$ crystal violet. The colonies were counted and scanned using a high-resolution scanner Scan Maker 9800XL (MiCROTEK, Hsinchu, Taiwan). 


\subsection{Antibody and Western Blot Assay}

Rabbit anti-human ERK, $p$-ERK, JNK, $p$-JNK, GRP78, ATF4, and cleaved-ATF6 antibodies were purchased from ProteinTech Group (Chicago, IL, USA). Rabbit anti-human antibodies against AKT, $p$-AKT, PI3K, $p$-PI3K, Mcl-1, Bad, $p$-Bad, Bcl-xl, Bcl-2, Bax, p38, $p$-p38, PERK, $p$-PERK, elF2 $\alpha, p$-elF2 $\alpha$, pro-caspase 3, cleaved caspase 3, pro-caspase 9, cleaved caspase 9, cytochrome $C$, and CHOP were obtained from Cell Signaling Technology (Danvers, MA, USA). Rabbit anti-human $\beta$-actin antibodies were obtained from Sigma (St Louis, MO, USA). Cytosolic cytochrome $C$ were separated using a cytochrome $C$ releasing apoptosis assay kit (Biovision, Milpitas, CA, USA).

The flaccidoxide-13-acetate treated sample and DMSO treated control samples (total protein $25 \mu \mathrm{g}$ ) were separated by $12.5 \%$ SDS-PAGE, and the proteins on the gel were transferred to a PVDF membrane. The membrane containing transferred protein was blocked in PBS buffer and incubated with primary antibody at $4{ }^{\circ} \mathrm{C}$ overnight, followed by secondary antibodies (goat anti-rabbit or goat anti-mouse and horseradish peroxidase conjugate, 1:5000 dilution in $2 \%$ dehydrated skim milk) for $2 \mathrm{~h}$ at $4{ }^{\circ} \mathrm{C}$. The signals were detected with an enhanced chemiluminescence detection kit.

\subsection{Inhibitor Assessment}

In order to further determine the effects of p38, ERK, and JNK on flaccidoxide-13-acetate-induced cell proliferation arrest, a total of $1 \times 10^{5}$ cells were seeded in a 24 well plate and pre-incubated for $2 \mathrm{~h}$ with specific inhibitors for p38 (SB2203580), JNK (SP600125), and ERK (PD98059) prior to flaccidoxide-13-acetate administration. Afterwards, the cell viability rate was determined by MTT assay.

\subsection{Statistical Analysis}

The results of the MTT assay and colony formation assay were subjected to Student's test (Sigma-Stat2.0, San Rafael, CA, USA). Results with $p<0.05$ were considered statistically significant.

\section{Conclusions}

In this study, we demonstrated that flaccidoxide-13-acetate induces apoptosis in RT4 and T24 bladder cancer cells, and the process is mediated by induction of mitochondrial dysfunction and activation of ER stress, which also involves initiation of the p38 and JNK pathways and inhibition of the PI3K/AKT pathway (Figure 6). Our findings revealed that flaccidoxide-13-acetate-induced apoptosis in bladder cancer cells occurs via multiple pathways. Further study of the underlying mechanism is underway in our laboratory to identify specific targets of flaccidoxide-13-acetate in bladder cancer cells. 


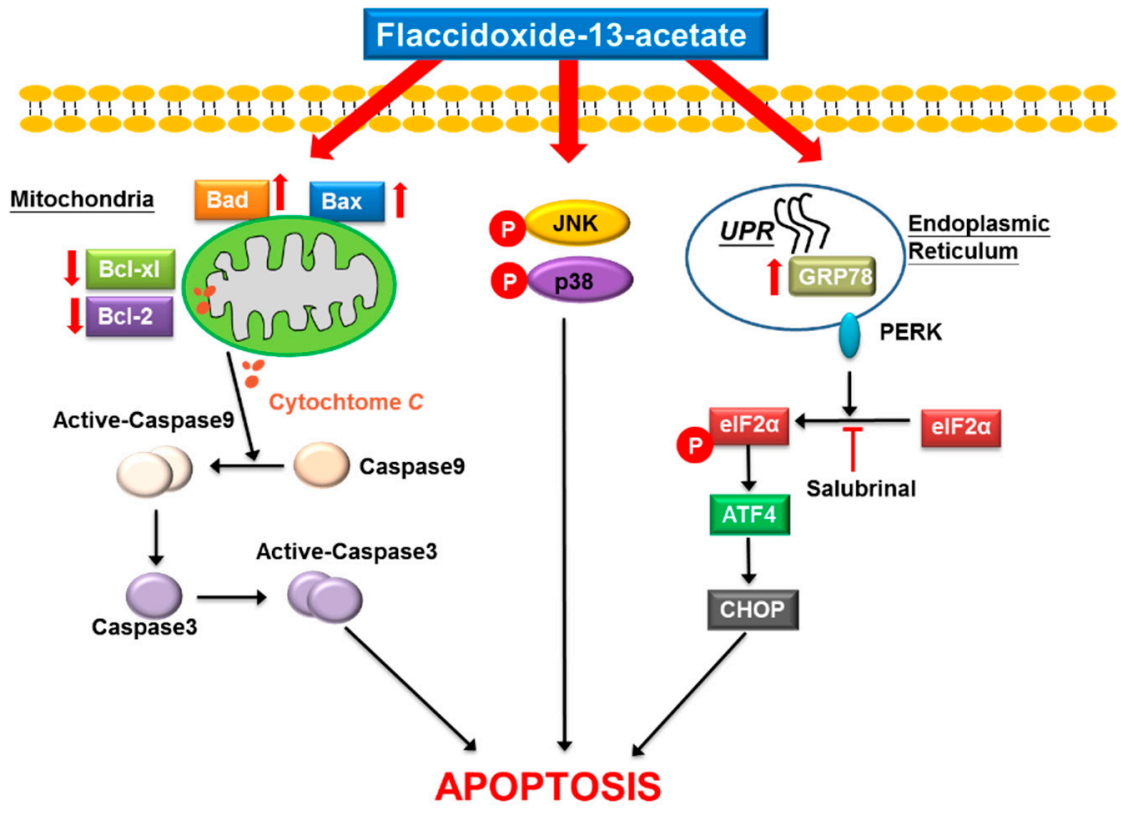

Figure 6. Flaccidoxide-13-acetate-induced apoptotic pathway in bladder cancer cells. The anti-cancer effect of flaccidoxide-13-acetate is mediated by the induction of mitochondria dysfunction and ER stress signaling pathways, also involving initiation of the p38 and JNK pathways.

Author Contributions: Y.-J.W. and C.-I.L. conceived and designed the experiments. J.-H.S. performed the sample collection, extraction, isolation, and structure determination; the pharmacological experiments were carried out by T.-R.S. and G.-F.D.; Y.-J.W. and C.-I.L. participated in data interpretation, wrote the manuscript, and revised the paper.

Funding: This research was funded by National Science Council Research (MOST 105-2313-B-276-001-MY3).

Acknowledgments: This study was supported in part by a grant from the National Science Council Research (MOST 105-2313-B-276-001-MY3) by Y.-J.W.

Conflicts of Interest: The authors declare no conflict of interest.

\section{References}

1. Carneiro, B.A.; Meeks, J.J.; Kuzel, T.M.; Scaranti, M.; Abdulkadir, S.A.; Giles, F.J. Emerging therapeutic targets in bladder cancer. Cancer Treat. Rev. 2015, 41, 170-178. [CrossRef] [PubMed]

2. Babjuk, M.; Burger, M.; Zigeuner, R.; Shariat, S.F.; van Rhijn, B.W.; Compérat, E.; Sylvester, R.J.; Kaasinen, E.; Böhle, A.; Redorta, J.P. Eau guidelines on non-muscle-invasive urothelial carcinoma of the bladder: Update 2013. Eur. Urol. 2013, 64, 639-653. [CrossRef] [PubMed]

3. Burger, M.; Catto, J.W.; Dalbagni, G.; Grossman, H.B.; Herr, H.; Karakiewicz, P.; Kassouf, W.; Kiemeney, L.A.; La Vecchia, C.; Shariat, S. Epidemiology and risk factors of urothelial bladder cancer. Eur. Urol. 2013, 63, 234-241. [CrossRef] [PubMed]

4. Knowles, M.A.; Hurst, C.D. Molecular biology of bladder cancer: New insights into pathogenesis and clinical diversity. Nat. Rev. Cancer 2015, 15, 25-41. [CrossRef] [PubMed]

5. Parekh, D.J.; Bochner, B.H.; Dalbagni, G. Superficial and muscle-invasive bladder cancer: Principles of management for outcomes assessments. J. Clin. Oncol. 2006, 24, 5519-5527. [CrossRef] [PubMed]

6. Chamie, K.; Litwin, M.S.; Bassett, J.C.; Daskivich, T.J.; Lai, J.; Hanley, J.M.; Konety, B.R.; Saigal, C.S. Urologic Diseases in America Project. Recurrence of high-risk bladder cancer: A population-based analysis. Cancer 2013, 119, 3219-3227. [CrossRef]

7. Radhika, P. Chemical constituents and biological activities of the soft corals of genus Cladiella: A review. Biochem. Syst. Ecol. 2006, 34, 781-789. [CrossRef]

8. Fan, M.; Nath, A.; Tang, Y.; Choi, Y.-J.; Debnath, T.; Choi, E.-J.; Kim, E.-K. Investigation of the anti-prostate cancer properties of marine-derived compounds. Mar. Drugs 2018, 16, 160. [CrossRef] 
9. Santacruz, L.; Thomas, O.P.; Duque, C.; Puyana, M.; Tello, E. Comparative analyses of metabolomic fingerprints and cytotoxic activities of soft corals from the colombian caribbean. Mar. Drugs 2019, 17, 37. [CrossRef]

10. Kamada, T.; Kang, M.-C.; Phan, C.-S.; Zanil, I.; Jeon, Y.-J.; Vairappan, C. Bioactive cembranoids from the soft coral genus Sinularia sp. In Borneo. Mar. Drugs 2018, 16, 99. [CrossRef]

11. Hou, P.; Zeng, Y.; Ma, B.; Bi, K.; Chen, X. A new cytotoxic cembrane diterpene from the roots of euphorbia pekinensis rupr. Fitoterapia 2013, 90, 10-13. [CrossRef]

12. Li, L.-M.; Li, G.-Y.; Pu, J.-X.; Xiao, W.-L.; Ding, L.-S.; Sun, H.-D. Ent-kaurane and cembrane diterpenoids from isodon sculponeatus and their cytotoxicity. J. Nat. Prod. 2009, 72, 1851-1856. [CrossRef]

13. Lin, Y.-S.; Chen, C.-H.; Liaw, C.-C.; Chen, Y.-C.; Kuo, Y.-H.; Shen, Y.-C. Cembrane diterpenoids from the taiwanese soft coral Sinularia flexibilis. Tetrahedron 2009, 65, 9157-9164. [CrossRef]

14. Chiang, P.-C.; Chien, C.-L.; Pan, S.-L.; Chen, W.-P.; Teng, C.-M.; Shen, Y.-C.; Guh, J.-H. Induction of endoplasmic reticulum stress and apoptosis by a marine prostanoid in human hepatocellular carcinoma. J. Hepatol. 2005, 43, 679-686. [CrossRef]

15. Kamel, H.N.; Ferreira, D.; Garcia-Fernandez, L.F.; Slattery, M. Cytotoxic diterpenoids from the hybrid soft coral Sinularia maxima $\times$ Sinularia polydactyla. J. Nat. Prod. 2007, 70, 1223-1227. [CrossRef]

16. Liu, C.-I.; Chen, C.-C.; Chen, J.-C.; Su, J.-H.; Huang, H.H.; Chen, J.Y.-F.; Wu, Y.-J. Proteomic analysis of anti-tumor effects of 11-dehydrosinulariolide on cal-27 cells. Mar. Drugs 2011, 9, 1254-1272. [CrossRef]

17. Neoh, C.-A.; Wang, R.Y.-L.; Din, Z.-H.; Su, J.-H.; Chen, Y.-K.; Tsai, F.-J.; Weng, S.-H.; Wu, Y.-J. Induction of apoptosis by sinulariolide from soft coral through mitochondrial-related and p38mapk pathways on human bladder carcinoma cells. Mar. Drugs 2012, 10, 2893-2911. [CrossRef]

18. Pachycladins, A. Prostate cancer invasion and migration inhibitory eunicellin-based diterpenoids from the red sea soft coral cladiella pachyclados hassan. Hossam M 2010, 73, 848-853.

19. Poza, J.J.; Fernandez, R.; Reyes, F.; Rodriguez, J.; Jimenez, C. Isolation, biological significance, synthesis, and cytotoxic evaluation of new natural parathiosteroids a $-\mathrm{c}$ and analogues from the soft coral Paragorgia sp. J. Organ. Chem. 2008, 73, 7978-7984. [CrossRef]

20. Su, C.-C.; Su, J.-H.; Lin, J.-J.; Chen, C.-C.; Hwang, W.-I.; Huang, H.H.; Wu, Y.-J. An investigation into the cytotoxic effects of 13-acetoxysarcocrassolide from the soft coral sarcophyton crassocaule on bladder cancer cells. Mar. Drugs 2011, 9, 2622-2642. [CrossRef]

21. Denicourt, C.; Dowdy, S.F. Targeting apoptotic pathways in cancer cells. Science 2004, 305, 1411-1413. [CrossRef]

22. Matthews, G.M.; Newbold, A.; Johnstone, R.W. Intrinsic and extrinsic apoptotic pathway signaling as determinants of histone deacetylase inhibitor antitumor activity. Adv. Cancer Res. 2012, 116, 165-197.

23. Ron, D.; Walter, P. Signal integration in the endoplasmic reticulum unfolded protein response. Nat. Rev. Mol. Cell Biol. 2007, 8, 519-529. [CrossRef]

24. Zielinski, R.R.; Eigl, B.J.; Chi, K.N. Targeting the apoptosis pathway in prostate cancer. Cancer J. 2013, 19, 79-89. [CrossRef]

25. Campbell, N.A.; Williamson, B.; Heyden, R.J. Biology: Exploring Life; Pearson Prentice Hall: Boston, MA, USA, 2006; ISBN 0-13-250882-6.

26. McBride, H.M.; Neuspiel, M.; Wasiak, S. Mitochondria: More than just a powerhouse. Curr. Biol. 2006, 16, R551-R560. [CrossRef]

27. Basañez, G.; Soane, L.; Hardwick, J.M. A new view of the lethal apoptotic pore. PLoS Biol. 2012, 10, e1001399. [CrossRef]

28. Green, D.R.; Reed, J.C. Mitochondria and apoptosis. Science 1998, 281, 1309-1312. [CrossRef]

29. Ballarin, L.; Burighel, P.; Cima, F. A tale of death and life: Natural apoptosis in the colonial ascidian botryllus schlosseri (Urochordata, Ascidiacea). Curr. Pharm. Des. 2008, 14, 138-147. [CrossRef]

30. Rao, R.V.; Ellerby, H.; Bredesen, D.E. Coupling endoplasmic reticulum stress to the cell death program. Cell Death Differ. 2004, 11, 372-380. [CrossRef]

31. Schröder, M.; Kaufman, R.J. The mammalian unfolded protein response. Annu. Rev. Biochem. 2005, 74, 739-789. [CrossRef]

32. Liu, C.Y.; Kaufman, R.J. The unfolded protein response. J. Cell Sci. 2003, 116, 1861-1862. [CrossRef] 
33. Sato, A.; Asano, T.; Okubo, K.; Isono, M.; Asano, T. Nelfinavir and ritonavir kill bladder cancer cells synergistically by inducing endoplasmic reticulum stress. Oncol. Res. Feat. Preclin. Clin. Cancer Ther. 2018, 26, 323-332. [CrossRef]

34. Xu, Y.; Tong, Y.; Ying, J.; Lei, Z.; Wan, L.; Zhu, X.; Ye, F.; Mao, P.; Wu, X.; Pan, R. Chrysin induces cell growth arrest, apoptosis, and er stress and inhibits the activation of stat 3 through the generation of ros in bladder cancer cells. Oncol. Lett. 2018, 15, 9117-9125. [CrossRef]

35. Zhang, M.; Du, H.; Huang, Z.; Zhang, P.; Yue, Y.; Wang, W.; Liu, W.; Zeng, J.; Ma, J.; Chen, G. Thymoquinone induces apoptosis in bladder cancer cell via endoplasmic reticulum stress-dependent mitochondrial pathway. Chem. Biol. Interact. 2018, 292, 65-75. [CrossRef]

36. Neoh, C.-A.; Wu, W.-T.; Dai, G.-F.; Su, J.-H.; Liu, C.-I.; Su, T.-R.; Wu, Y.-J. Flaccidoxide-13-acetate extracted from the soft coral cladiella kashmani reduces human bladder cancer cell migration and invasion through reducing activation of the fak/pi3k/akt/mtor signaling pathway. Molecules 2017, 23, 58. [CrossRef]

37. Lenaz, G.; Bovina, C.; D'aurelio, M.; Fato, R.; For miggini, G.; Genova, M.L.; Giuliano, G.; Pich, M.M.; Paolucci, U.; Castelli, G.P. Role of mitochondria in oxidative stress and aging. Ann. N. Y. Acad. Sci. 2002, 959, 199-213. [CrossRef]

38. Pearson, G.; Robinson, F.; Beers Gibson, T.; Xu, B.-E.; Karandikar, M.; Berman, K.; Cobb, M.H. Mitogen-activated protein (map) kinase pathways: Regulation and physiological functions. Endocr. Rev. 2001, 22, 153-183.

39. Ron, D. Translational control in the endoplasmic reticulum stress response. J. Clin. Investig. 2002, 110, $1383-1388$. [CrossRef]

40. Kim, I.; Xu, W.; Reed, J.C. Cell death and endoplasmic reticulum stress: Disease relevance and therapeutic opportunities. Nat. Rev. Drug Discov. 2008, 7, 1013-1030. [CrossRef]

41. Xu, C.; Bailly-Maitre, B.; Reed, J.C. Endoplasmic reticulum stress: Cell life and death decisions. J. Clin. Investig. 2005, 115, 2656-2664. [CrossRef]

42. Kouroku, Y.; Fujita, E.; Tanida, I.; Ueno, T.; Isoai, A.; Kumagai, H.; Ogawa, S.; Kaufman, R.; Kominami, E.; Momoi, T. Er stress (perk/eif2 $\alpha$ phosphorylation) mediates the polyglutamine-induced lc3 conversion, an essential step for autophagy formation. Cell Death Differ. 2007, 14, 230-239. [CrossRef]

43. Oyadomari, S.; Mori, M. Roles of chop/gadd153 in endoplasmic reticulum stress. Cell Death Differ. 2004, 11, 381-389. [CrossRef]

44. Shimizu, S.; Tsujimoto, Y. Proapoptotic bh3-only bcl-2 family members induce cytochrome c release, but not mitochondrial membrane potential loss, and do not directly modulate voltage-dependent anion channel activity. Proc. Natl. Acad. Sci. USA 2000, 97, 577-582. [CrossRef]

45. González-Gironès, D.M.; Moncunill-Massaguer, C.; Iglesias-Serret, D.; Cosialls, A.M.; Pérez-Perarnau, A.; Palmeri, C.M.; Rubio-Patiño, C.; Villunger, A.; Pons, G.; Gil, J. Aicar induces bax/bak-dependent apoptosis through upregulation of the bh3-only proteins bim and noxa in mouse embryonic fibroblasts. Apoptosis 2013, 18, 1008-1016. [CrossRef]

46. Gotoh, M.; Sano-Maeda, K.; Murofushi, H.; Murakami-Murofushi, K. Protection of neuroblastoma neuro2a cells from hypoxia-induced apoptosis by cyclic phosphatidic acid (cpa). PLoS ONE 2012, 7, e51093. [CrossRef]

47. Hoshyar, R.; Bathaie, S.Z.; Sadeghizadeh, M. Crocin triggers the apoptosis through increasing the bax/bcl-2 ratio and caspase activation in human gastric adenocarcinoma, ags, cells. DNA Cell Biol. 2013, 32, 50-57. [CrossRef]

48. Kaparou, M.; Choumerianou, D.; Perdikogianni, C.; Martimianaki, G.; Kalmanti, M.; Stiakaki, E. Enhanced levels of the apoptotic bax/bcl-2 ratio in children with acute lymphoblastic leukemia and high-risk features. Genet. Mol. Biol. 2013, 36, 7-11. [CrossRef]

49. Nicholson, D.W.; Thornberry, N.A. Life and death decisions. Science 2003, 299, 214-215. [CrossRef]

50. Chang, L.; Karin, M. Mammalian map kinase signalling cascades. Nature 2001, 410, 37-40. [CrossRef]

51. Santarpia, L.; Lippman, S.M.; El-Naggar, A.K. Targeting the mapk-ras-raf signaling pathway in cancer therapy. Expert Opin. Ther. Targets 2012, 16, 103-119. [CrossRef]

52. Coulthard, L.R.; White, D.E.; Jones, D.L.; McDermott, M.F.; Burchill, S.A. P38mapk: Stress responses from molecular mechanisms to therapeutics. Trends Mol. Med. 2009, 15, 369-379. [CrossRef]

53. Masmoudi-Kouki, O.; Douiri, S.; Hamdi, Y.; Kaddour, H.; Bahdoudi, S.; Vaudry, D.; Basille, M.; Leprince, J.; Fournier, A.; Vaudry, H. Pituitary adenylate cyclase-activating polypeptide protects astroglial cells against oxidative stress-induced apoptosis. J. Neurochem. 2011, 117, 403-411. [CrossRef] 
54. Sever, R.; Brugge, J.S. Signal transduction in cancer. Cold Spring Harb. Perspect. Med. 2015, 5, a006098. [CrossRef]

55. Sweatt, J.D. The neuronal map kinase cascade: A biochemical signal integration system subserving synaptic plasticity and memory. J. Neurochem. 2001, 76, 1-10. [CrossRef]

56. Dhillon, A.S.; Hagan, S.; Rath, O.; Kolch, W. Map kinase signalling pathways in cancer. Oncogene 2007, 26, 3279-3290. [CrossRef]

57. Janku, F.; Wheler, J.J.; Westin, S.N.; Moulder, S.L.; Naing, A.; Tsimberidou, A.M.; Fu, S.; Falchook, G.S.; Hong, D.S.; Garrido-Laguna, I. Pi3k/akt/mtor inhibitors in patients with breast and gynecologic malignancies harboring pik3ca mutations. J. Clin. Oncol. 2012, 30, 777-782. [CrossRef]

58. Cantley, L.C.; Auger, K.R.; Carpenter, C.; Duckworth, B.; Graziani, A.; Kapeller, R.; Soltoff, S. Oncogenes and signal transduction. Cell 1991, 64, 281-302. [CrossRef]

59. Ikeda, S.; Kishida, S.; Yamamoto, H.; Murai, H.; Koyama, S.; Kikuchi, A. Axin, a negative regulator of the wnt signaling pathway, forms a complex with gsk- $3 \beta$ and $\beta$-catenin and promotes gsk-3 $\beta$-dependent phosphorylation of $\beta$-catenin. EMBO J. 1998, 17, 1371-1384. [CrossRef]

60. Yang, E.; Zha, J.; Jockel, J.; Boise, L.H.; Thompson, C.B.; Korsmeyer, S.J. Bad, a heterodimeric partner for bcl-xl and bcl-2, displaces bax and promotes cell death. Cell 1995, 80, 285-291. [CrossRef]

61. Zha, J.; Harada, H.; Yang, E.; Jockel, J.; Korsmeyer, S.J. Serine phosphorylation of death agonist bad in response to survival factor results in binding to 14-3-3 not bcl-xl. Cell 1996, 87, 619-628. [CrossRef]

62. Hong, S.-W.; Shin, J.-S.; Moon, J.-H.; Kim, Y.-S.; Lee, J.; Choi, E.K.; Ha, S.-H.; Lee, D.H.; Chung, H.N.; Kim, J.E. Nvp-bez235, a dual pi3k/mtor inhibitor, induces cell death through alternate routes in prostate cancer cells depending on the pten genotype. Apoptosis 2014, 19, 895-904. [CrossRef]

63. Liu, M.; Li, C.-M.; Chen, Z.-F.; Ji, R.; Guo, Q.-H.; Li, Q.; Zhang, H.-L.; Zhou, Y.-N. Celecoxib regulates apoptosis and autophagy via the pi3k/akt signaling pathway in sgc-7901 gastric cancer cells. Int. J. Mol. Med. 2014, 33, 1451-1458. [CrossRef]

64. Araki, K.; Nagata, K. Protein folding and quality control in the ER. Cold Spring Harb. Perspect. Biol. 2011, 3, a007526. [CrossRef]

65. Saito, A.; Ochiai, K.; Kondo, S.; Tsumagari, K.; Murakami, T.; Cavener, D.R.; Imaizumi, K. Endoplasmic reticulum stress response mediated by the perk-eif $2 \alpha$-atf 4 pathway is involved in osteoblast differentiation induced by bmp2. J. Biol. Chem. 2011, 286, 4809-4818. [CrossRef]

66. Yan, W.; Frank, C.L.; Korth, M.J.; Sopher, B.L.; Novoa, I.; Ron, D.; Katze, M.G. Control of perk eif2 $\alpha$ kinase activity by the endoplasmic reticulum stress-induced molecular chaperone p58ipk. Proc. Natl. Acad. Sci. USA 2002, 99, 15920-15925. [CrossRef]

67. Cullinan, S.B.; Diehl, J.A. Coordination of er and oxidative stress signaling: The perk/nrf2 signaling pathway. Int. J. Biochem. Cell Biol. 2006, 38, 317-332. [CrossRef]

68. Marciniak, S.J.; Garcia-Bonilla, L.; Hu, J.; Harding, H.P.; Ron, D. Activation-dependent substrate recruitment by the eukaryotic translation initiation factor 2 kinase perk. J. Cell Biol. 2006, 172, 201-209. [CrossRef]

69. Liu, Z.-W.; Zhu, H.-T.; Chen, K.-L.; Dong, X.; Wei, J.; Qiu, C.; Xue, J.-H. Protein kinase rna-like endoplasmic reticulum kinase (perk) signaling pathway plays a major role in reactive oxygen species (ros)-mediated endoplasmic reticulum stress-induced apoptosis in diabetic cardiomyopathy. Cardiovasc. Diabetol. 2013, 12, 158. [CrossRef]

70. Matsumoto, H.; Miyazaki, S.; Matsuyama, S.; Takeda, M.; Kawano, M.; Nakagawa, H.; Nishimura, K.; Matsuo, S. Selection of autophagy or apoptosis in cells exposed to er-stress depends on atf4 expression pattern with or without chop expression. Biol. Open 2013, 2, 1084-1090. [CrossRef]

71. Toth, A.; Nickson, P.; Mandl, A.; Bannister, M.L.; Toth, K.; Erhardt, P. Endoplasmic reticulum stress as a novel therapeutic target in heart diseases. Cardiovasc. Haematol. Disord. Drug Targets 2007, 7, 205-218. [CrossRef]

(C) 2019 by the authors. Licensee MDPI, Basel, Switzerland. This article is an open access article distributed under the terms and conditions of the Creative Commons Attribution (CC BY) license (http://creativecommons.org/licenses/by/4.0/). 